\title{
Konsep Inovasi Strategi Pendidikan di Institusi Pendidikan Kedokteran
}

\author{
Yoyo Suhoyo \\ Fakultas Kedokteran Universitas Gadjah Mada \\ Yogyakarta
}

\begin{abstract}
Innovation in medical education is essentially a reaction towards various demands and changes in the medical education institutions environment. The innovation of educational strategy is a part of the effort. Innovation in medical education should consider the feasibility level, resources needed, time and duration of implementation, scale and degree, that failure can occur, obstacles faced and the pattern of innovation that will be done. Considering the current condition of medical education institutions that are known through self-evaluation and strategic plan, and a growing trend in medical education at this time, severalinnovation can be proposed. SPICES approach can be taken as a guide in designing innovation in medical education.
\end{abstract}

Keywords: innovation, SPICES, medical education institution

\begin{abstract}
Abstrak
Inovasi pendidikan kedokteran merupakan hal mendasar dan penting sebagai konsekuensi dari bermacam-macam tuntutan dan perubahan yang terjadi di lingkungan institusi pendidikan kedokteran. Inovasi strategi pendidikan merupakan bagian dari hal tersebut. Dalam merancang suatu inovasi itu sendiri, setiap institusi pendidikan kedokteran harus mempertimbangkan tingkat kelayakan, sumber daya yang dibutuhkan, waktu dan durasi pelaksanaan, skala dan derajat kegagalan yang mungkin terjadi, hambatan yang dihadapi dan pola inovasi yang akan dilakukan. Dengan memperhatikan kondisi saat ini dari institusi pendidikan kedokteran yang dikenal melalui evaluasi diri dan rencana stratejik, dan trend yang berkembang di pendidikan kedokteran saat ini, maka dapat diusulkan beberapa inovasi yang dapat dilakukan. Pendekatan SPICES dapat dilakukan sebagai panduan dalam mendesain inovasi-inovasi pendidikan kedokteran.
\end{abstract}

Kata Kunci: inovasi, SPICES, institusi pendidikan kedokteran

\section{PENDAHULUAN}

Kondisi politik, demografi, teknologi, ekonomi, pelayanan kesehatan, epidemiologi penyakit dan pendidikan di dunia saat ini telah mengalami perubahan. ${ }^{1}$ Demokrasi menjadi tuntutan perubahan politik dunia. Jumlah penduduk terus bertambah. Ilmu pengetahuan dan teknologi kedokteran terus berkembang pesat. Pola penyakit yang dahulu banyak didominasi penyakit akut kini bergeser kepada penyakit kronis. Pelayanan kesehatan menjadi lebih menekankan pentingnya pencegahan. Privatisasi pusat pelayanan kesehatan meningkat diiringi peningkatan biaya pelayanan kesehatan. Penyakit-penyakit jenis baru bermunculan. Sementara penyebaran dokter dan tenaga kesehatan lain tidak merata dan akses mendapatkan pelayanan kesehatan semakin terbatas khususnya bagi masyarakat miskin. Di sisi lain, kesadaran pasien semakin meningkat akibat arus informasi terbuka, kebutuhan multiprofessional team meningkat dan beban kerja dokter bertambah dengan adanya tugas penelitian dan pendidikan. Tuntutan akan pendidikan yang sesuai kebutuhan, dapat dipertanggungjawabkan dan diperbanyaknya spesialisasi, ditambah

Korespondensi: yo2suhoyo@yahoo.com, Telp: 0274-562139

Bagian Pendidikan Kedokteran FK UGM, Gd. Radiopoetro Lt 6. Jl. Farmako Sekip Utara Yogyakarta 
jumlah mahasiswa yang semakin meningkat adalah kecenderungan perubahan dalam dunia pendidikan. Berbagai perubahan tersebut pada dasarnya merupakan tantangan bagi masyarakat global untuk mampu beradaptasi dan tidak tertinggal. Institusi pendidikan kedokteran yang merupakan bagian dari masyarakat global, sudah seharusnya ikut serta melakukan perubahan tersebut. Inovasi strategi pendidikan adalah bagian dari upaya perubahan yang harus dilakukan institusi pendidikan kedokteran.

World Federation for Medical Education (WFME) telah merekomendasikan standar global bagi institusi pendidikan kedokteran di seluruh dunia. ${ }^{2}$ Di Indonesia, standar global ini kemudian menjadi dasar penyusunan Standar Kompetensi Dokter dan Standar Pendidikan Profesi Kedokteran oleh Konsil Kedokteran Indonesia (KKI). ${ }^{3,4}$ Kedua standar tersebut menetapkan berbagai ketentuan yang seharusnya dilakukan oleh institusi pendidikan kedokteran dalam melaksanakan proses pendidikannya, termasuk di dalamnya adalah ketentuan tentang strategi pendidikan. WFME mendorong strategi pendidikan self directed learning yang menyiapkan mahasiswa menjadi life long learner. ${ }^{2}$ KKI menetapkan model Kurikulum Berbasis Kompetensi (KBK) dengan pendekatan terintegrasi (horizontal dan vertikal), berorientasi kesehatan individu, keluarga dan masyarakat dalam konteks pelayanan kesehatan primer dengan menggunakan strategi SPICES (Student centred, Problem based, Integrated, Comunity-based, Elective/Early clinical exposure, Systematic). ${ }^{3}$ Ketentuan-ketentuan tersebut pada dasarnya adalah bentuk inovasi dalam strategi pendidikan kedokteran saat ini, yang dengan sendirinya harus dilaksanakan oleh Institusi pendidikan kedokteran.

\section{STRATEGI PENDIDIKAN KEDOKTERAN}

Ada 9 (sembilan) kecenderungan atau trend pendidikan kedokteran yang sedang berkembang saat ini. ${ }^{1}$ Trend pertama adalah pendidikan untuk mencapai kemampuan atau kompetensi atau kapabilitas (capability). Pendidikan kedokteran yang selama ini bersifat umum sehingga kurikulum sangat padat, sekarang lebih ditujukan kepada kompetensi yang dibutuhkan. Hal ini ditandai adanya standar kompetensi minimal yang harus dicapai (kurikulum inti) dan kurikulum pilihan, pentingnya latihan keterampilan klinik, dan diperlukannya kompetensi umum. Yang dimaksud kompetensi umum adalah kompetensi bioetika, keterampilan komunikasi, keterampilan hubungan interpersonal, kemampuan pemecahan masalah, keterampilan manajemen dan organisasi, bekerja dalam kelompok, keterampilan teknologi informasi dan hubungan dokter pasien. Trend kedua adalah community orientation in medical education (COME). Pendidikan kedokteran diarahkan pada kebutuhan masyarakat baik individu atau kelompok, serta ditujukan pada pembelajaran promosi kesehatan, pencegahan penyakit, penilaian dan pemenuhan kebutuhan masyarakat, dan kesadaran akan peran faktor lingkungan dan sosial dalam timbulnya penyakit. Trend ketiga adalah belajar terpusat pada mahasiswa (self directed learning/learnercentred learning). Trend ini dilandasi teori belajar orang dewasa (adult learning)yang mensyaratkan peran aktif mahasiswa dalam proses pembelajaran. Trend keempat adalah problem based learning (PBL) dan Task Based Learning (TBL) yang merupakan perwujudan dari self directed dan learnercentred learning. Jika PBL didasarkan pada skenario di atas kertas, maka TBL didasarkan kepada tugas nyata yang dipraktikkan di lapangan oleh profesi kedokteran. Trend kelima adalah integrasi dan kontak atau paparan dini dengan pasien (early clinical contact/exposure). Trend ini mendorong pendekatan disiplin ilmu menjadi lebih terintegrasi antar disiplin dan antar profesi. Trend keenam adalah pendidikan dokter berkelanjutan (continuing professional development/CPD). Hal ini didasari akan pentingnya pembelajaran sepanjang hayat bagi profesi kedokteran sebagai wujud tanggung jawab profesi. Trend ketujuh adalah penyatuan antara pendidikan dan praktik. Pendidikan kedokteran harus memiliki akses ke pusat-pusat pelayanan yang ada di tengah masyarakat agar terjadi proses yang berkesinambungan antara pendidikan dan kebutuhan masyarakat. Trend kedelapan adalah pendidikan kedokteran berdasarkan fakta (best evidence on medical education/BEME). Keputusan medis dokter yang harus didasari oleh fakta berupa temuan ilmiah, harus diikuti dengan proses pendidikan dokter yang juga didasari oleh bukti ilmiah, bukan karena tradisi, kebiasaan atau asumsi semata. Terakhir, trend kesembilan adalah keberadaan teknologi informasi dan komunikasi (information and communication technology/ICT). Perkembangan dibidang ICT telah memberikan pengaruh kepada dunia penelitian, pelayanan dan pendidikan. Pada satu sisi, setiap dokter dituntut memahami dan mampu menggunakan teknologi ICT dalam pelayanan, penelitian dan pedidikan, dan pada sisi yang lain ICT dapat digunakan untuk kepentingan 
proses pendidikan dokter itu sendiri. Kesembilan trend ini dapat dijadikan tolok ukur inovasi di suatu institusi pendidikan kedokteran.

Senada dengan perkembangan atau trend di atas, Harden mengajukan model strategi SPICES dalam pendidikan kedokteran. ${ }^{6}$ SPICES merupakan rangkaian strategi pendidikan yang tersusun dari Student centred, Problem based, Integrated/Interprofessional education, Comunity based, Elective/Early clinical exposure dan Systematic. Pendekatan ini lahir sebagai suatu inovasi akan strategi pendidikan yang ada sebelumnya, yaitu Teacher centred, Information oriented, subject/discipline based, Hospital based, Uniform dan opportunistic. Model ini menjadi strategi pendidikan yang harus digunakan oleh seluruh institusi pendidikan kedokteran di Indonesia karena merupakan standar yang telah ditetapkan KKI.

\section{INOVASI STRATEGI PENDIDIKAN}

Merancang inovasi strategi pendidikan adalah bagian dari langkah-langkah menerapkan inovasi pendidikan, yaitu (1) mengidentifikasi masalah bersama, (2) menilai kekuatan untuk melakukan perubahan, (3) merancang inovasi, (4) melakukan konsultasi, (5) melakukan publikasi secara luas, (6) menyepakati rencana rinci, (7) menerapkan inovasi, (8) menyediakan sarana pendukung, (9) memodifikasi rencana dan (10) mengevaluasi hasil. Inovasi baru dapat dilaksanakan setelah mengidentifikasi masalah institusi dan menilai kekuatan yang dimiliki untuk melakukan suatu perubahan. Dalam merancang suatu inovasi itu sendiri, setiap institusi pendidikan kedokteran harus mempertimbangkan tingkat kelayakan, sumber daya yang dibutuhkan, waktu dan durasi pelaksanaan, skala dan derajat, kegagalan yang dapat terjadi, hambatan yang dihadapi dan pola inovasi yang akan dilakukan.

Dengan mempertimbangkan kondisi terkini, trend yang berkembang dalam dunia pendidikan kedokteran dan model strategi SPICES, berikut ini adalah inovasi strategi pendidikan yang dapat dilakukan institusi pendidikan kedokteran di Indonesia:

\section{Student Centred}

Yang dimaksud dengan terpusat pada mahasiswa adalah mahasiswa sebagai orang dewasa diberi tanggung jawab untuk mengelola pembelajarannya secara mandiri. ${ }^{1,6} \mathrm{Ada}$ enam prinsip belajar secara mandiri, yaitu; (1) mahasiswa belajar menurut caranya sendiri, (2) mahasiswa memiliki ketentuan sendiri dalam mengelola proses pembelajarannya menyangkut tempat, materi, sumber, cara dan waktu belajar, (3) mahasiswa didorong untuk mengembangkan rencana belajar sendiri, (4) perbedaan kebutuhan belajar setiap individu diperhatikan dan diberi tanggapan khusus per individu tersebut, (5) pembelajaran mahasiswa didukung dengan penyediaan sumber dan panduan belajar, dan (6) peran dosen berubah dari penyampai informasi menjadi manajer proses pembelajaran. ${ }^{6}$

Dalam memfasilitasi proses belajar mandiri sebagai penerapan strategi student centred, institusi pendidikan kedokteran dapat melakukan hal-hal sebagai berikut: ${ }^{6}$

a. memberi peluang jumlah waktu yang cukup bagi mahasiswa untuk belajar mandiri (25-75\%)

b. memberikan pengakuan resmi secara institusional proses belajar mandiri dengan:

- memasukkan secara tertulis komponen belajar mandiri di dalam kurikulum, dan ditunjukkan dengan memasukkan kegiatan belajar mandiri ke dalam jadwal kegiatan belajar mahasiswa (intrakurikuler)

- menyediakan sumber belajar yang sesuai dengan kebutuhan

- menyediakan perangkat penilaian belajar mandiri

- program pengembangan staf agar mampu menjadi manajer proses pembelajaran dengan baik, contohnya melalui pelatihan

c. menawarkan pilihan berbagai jenis media belajar kepada mahasiswa

d. menyediakan panduan belajar untuk membantu memudahkan proses belajar mandiri

Seiring dengan perkembangan teknologi informasi dan komunikasi, institusi pendidikan kedokteran dapat memanfaatkannya untuk kepentingan belajar mandiri. ${ }^{6,8}$ Inovasi yang dapat dilakukan adalah dengan mengembangkan sistem informasi berbasis intranet untuk kepentingan akademik. Sistem informasi ini nantinya digunakan oleh mahasiswa untuk kepentingan proses pendidikan. Sistem informasi yang dimaksud adalah sistem yang berisi informasi sebagai berikut:

a. Biodata, yaitu data pribadi setiap mahasiswa 
b. Panduan Akademik, yaitu uraian tentang panduan proses pembelajaran, mulai dari kurikulum sampai aturan-aturan akademik

c. Jadwal Kegiatan Akademik, yaitu rincian jadwal kegiatan harian mulai masuk sebagai mahasiswa baru sampai lulus menjadi Sarjana Kedokteran

d. Jadwal Kegiatan Lembaga Mahasiswa (Ekstrakurikuler), yaitu jadwal kegiatan ekstrakurikuler lembaga-lembaga mahasiswa yang dapat diikuti

e. Daftar Nilai, yaitu daftar nilai mahasiswa dari tahun pertama sampai selesai menjadi dokter

f. Sumber Belajar (E-learning), yaitu materi pembelajaran yang berupa materi kuliah, catatan kuliah, dan bahan pustaka lain seperti jurnal, buku teks atau media audiovisual yang semuanya disediakan dalam bentuk digital

g. Ruang Konsultasi dan Komunikasi, yaitu program komputer yang memfasilitasi konsultasi dan komunikasi antara mahasiswa dengan dosen pembimbing akademik (DPA) atau dengan dosen pakar. Mahasiswa dapat menyampaikan pendapat, keluhan, pertanyaan atau permasalahan yang dihadapi selama proses pembelajaran yang kemudian akan ditanggapi oleh DPA atau dosen yang berwenang sesuai dengan kebutuhan individu mahasiswa

h. Jadwal Kegiatan Rotasi Klinik, yaitu jadwal rotasi di seluruh bagian klinik sejak mahasiswa lulus menjadi sarjana kedokteran sampai menjadi dokter. Jadwal ini baru dapat diakses jika mahasiswa telah lulus S1 dan telah mendaftarkan diri mengikuti rotasi klinik

i. Sumber Belajar Rotasi Klinik (Elearning Rotasi Klinik), yaitu materi pembelajaran yang diperlukan oleh mahasiswa di setiap bagian klinik dan akan dapat dihubungkan dengan materi pembelajaran di S1. Mahasiswa dapat mengakses informasi tidak hanya saat ada di kampus atau Rumah Sakit Pendidikan Utama tetapi juga saat berada di rumah sakit jejaring

j. Log Book, yaitu catatan atau laporan kegiatan pembelajaran yang dilakukan mahasiswa di setiap blok dan di setiap rotasi klinik. Log book akan diberi umpan balik oleh DPA

k. Portofolio, yaitu tugas yang harus dikerjakan oleh setiap mahasiswa pada setiap blok. Mahasiswa membuat laporan dan mengumpulkannya melalui sistem informasi ini dalam bentuk file. Tugas ini akan dijadikan sebagai portofolio mahasiswa dan akan mendapatkan nilai serta umpan balik dari Tim Koordinator Blok

1. Informasi Pendukung Pendidikan, yaitu informasi tentang kost, peta kota Yogyakarta, transportasi, pusat-pusat perbelanjaan, tips-tips belajar, soal-soal latihan ujian dan berbagai informasi yang membantu memudahkan mahasiswa dalam mengikuti proses pembelajaran di institusi pendidikan kedokteran

Sistem informasi tersebut bersifat individu. Setiap mahasiswa akan mendapatkan password dan hanya dapat melihat, membaca, berkonsultasi dan mengirimkan tugas pada tempatnya sendiri yang disediakan pada sistem ini. Dosen, DPA dan TKB dapat berinteraksi dan menggunakan informasi mahasiswa sesuai dengan kewenangannya/tugasnya masing-masing yang telah diatur dalam sistem informasi ini. Kerahasiaan mahasiswa, dosen, DPA dan TKB serta pihak lain yang terkait sangat dilindungi. Mahasiswa dapat mengakses datanya selama terdaftar sebagai mahasiswa (mengikuti registrasi) sampai 5 tahun setelah ia lulus menjadi dokter.

Selain dalam bentuk elektronik, penyediaan buku panduan belajar (Study guide) dalam bentuk cetak juga tetap dilakukan. Study guide tidak hanya dibuat di tingkat S1 tetapi juga di tingkat profesi (rotasi klinik).

\section{Problem Based Learning}

PBL telah dilaksanakan secara penuh di beberapa Program Studi Pendidikan Dokter di Indonesia. Yang perlu disempurnakan antara lain:

a. Penyediaan sumber belajar elektronik (e-learning) untuk setiap mahasiswa (telah dijelaskan pada bagian sebelumnya). ${ }^{6,8}$

b. Optimalisasi kegiatan kuliah sebagai kegiatan konsultasi antara mahasiswa dengan pakar terkait topik pembelajaran dalam skenario, tidak hanya penyampaian informasi.6,9

c. Penambahan satu kegiatan berupa diskusi terbuka antara mahasiswa dengan Tim Koordinator Blok untuk mendiskusikan materi atau masalah yang dihadapi mahasiswa dalam suatu skenario.9 Kegiatan diskusi dapat dilakukan setelah diskusi 
tutorial ke dua (langkah ke tujuh) pembahasan satu skenario dan sebelum diskusi tutorial untuk membahas skenario berikutnya.

d. Pembahasan tentang profesionalitas dokter (bioetika) yang terintegrasi dalam pembahasan skenario harus menjadi bagian dari diskusi tutorial, misal pada saat pertemuan kedua (langkah ketujuh). ${ }^{8,9} \mathrm{Hal}$ ini harus tercantum dalam tujuan belajar fakultas di setiap skenario sehingga diketahui oleh setiap tutor. Setiap skenario sebaiknya mengandung pembahasan tentang profesionalitas dokter. Namun jika tidak memungkinkan, dalam setiap blok harus ada pembahasan terkait profesionalitas dokter. Jika dalam diskusi tutorial kesulitan, pembahasan dapat dilakukan dalam diskusi kelas besar, dimana seluruh mahasiswa terlibat dan menjadi bagian setiap skenario minimal setiap blok.

e. Pengembangan skenario tidak hanya dalam bentuk tertulis tetapi juga dalam bentuk audiovisual (multimedia) sehingga dapat memicu proses pembelajaran secara lebih optimal.

\section{Integrated}

Institusi pendidikan kedokteran di Indonesia mulai banyak menerapkan strategi integrasi sejak dikeluarkannya standar kompetensi dokter dan standar pendidikan dokter oleh KKI tahun 2006. Meskipun demikian, masih perlu dilakukan upaya optimalisasi dalam integrasi ini khususnya integrasi antara pendidikan pre-klinik dengan klinik. Paparan mahasiswa terhadap kegiatan praktik klinik terkonsentrasi dalam pendidikan profesi atau rotasi klinik. Pembelajaran keterampilan medis di laboratorium keterampilan medis (skills lab) harus lebih dioptimalkan. Integrasi lainnya yang masih belum optimal adalah integrasi dengan kebutuhan masyarakat atau yang dikenal dengan community oriented, apalagi jika mengingat kompetensi utama yang diharapkan adalah menjadi dokter keluarga. ${ }^{6,8,10}$ Konsep ideal adalah dengan melaksanakan Community Based Medical Education (CBME). Namun mengingat konsekuensi dana dan fasilitas yang besar maka yang dapat dilakukan adalah modifikasi dengan pendidikan berorientasi komunitas. Penjelasan detail inovasi yang dapat dilakukan dapat dilihat pada bagian Community Oriented Medical Education (COME).
Integrasi mahasiswa sebagai pelajar adalah komponen integrasi yang juga harus diperhatikan. Konsep self directed learning yang berdasar pada paham konstruktivisme akan berujung pada individualisme jika tidak dikelola dengan baik. ${ }^{6}$ Institusi pendidikan khususnya tim kurikulum harus merancang strategi pembelajaran yang memungkinkan mahasiswa mampu belajar mandiri tanpa meninggalkan kebersamaan dan kerjasama. Penyediaan panduan belajar (study guide), log book, portofolio dan materi online (e-learning) seperti dijelaskan sebelumnya adalah contoh optimalisasi yang dapat dilakukan. Pemberian tugas atau proyek kelompok juga dapat dilakukan.

\section{Interprofessional Education}

Interprofessional education didefinisikan World Health Organization (WHO) sebagai suatu proses dimana suatu kelompok mahasiswa berbagai bidang kesehatan belajar bersama pada suatu periode pendidikan mereka, berinteraksi dan bekerja bersama-sama menyediakan pelayanan promotif, preventif, kuratif dan rehabilitatif dan pelayanan kesehatan lainnya. ${ }^{6,11}$ Definisi lainnya adalah suatu proses dimana dua atau lebih profesi yang berbeda saling belajar dari dan tentang profesi masingmasing untuk memperbaiki kerjasama dan kualitas pelayanan. Istilah lain yang sering digunakan adalah multiprofessional education. ${ }^{6,11}$ Interprofessional education diperlukan karena adanya kesadaran bahwa pelayanan kesehatan tidak dapat dilakukan oleh hanya satu profesi, melainkan kerjasama antar profesi. Kerjasama tidak dapat muncul begitu saja tanpa upaya yang sengaja. Diperlukan upaya membangun kerjasama tersebut sejak masih dalam proses pendidikan. Meskipun demikian, pendidikan interprofesional yang tidak tepat dilakukan justru akan mengakibatkan dampak yang kurang baik.

Ada tiga hal yang harus diperhatikan dalam pendidikan interprofesional, yaitu konteks pembelajaran, tujuan pendidikan dan strategi pendidikan. ${ }^{6}$ Konteks pembelajaran meliputi waktu pelaksanaan pendidikan (di tingkat sarjana atau profesi), tempat pendidikan (misalnya di kelas atau tempat praktik atau komunitas), topik atau materi pendidikannya (misalnya peran setiap profesi dalam pelayanan, kerjasama, etika dan pelayanan paliatif) dan pendekatan belajar (misalnya diskusi kelompok, kuliah, PBL atau mengerjakan proyek bersama). Tujuan pendidikan mencakup keterampilan bekerjasama dan kemampuan untuk bekerja sebagai anggota suatu tim. Secara rinci tujuan pendidikan interprofesional sebaiknya adalah: ${ }^{6,11}$ 
a. kompetensi inti yang membedakan setiap profesi, menyangkut pengetahuan keterampilan dan sikap perilaku setiap profesi dalam pemberian pelayanan.

b. berbagai keterampilan bekerjasama dalam memberikan pelayanan sesuai dengan batasan kewenangan masing-masing profesi.

c. pembiasaan dan pemahaman akan peran masingmasing profesi dan apresiasinya terhadap pelayanan kesehatan menurut pandangan setiap profesi.

d. keterampilan terkait membentuk tim, bekerjasama, dan berkomunikasi yang akan berguna dalam bekerja dalam suatu tim kesehatan.

Strategi pendidikan meliputi pelaksanaan langkahlangkah proses interprofessional education. Harden menyebutkan ada 11 langkah pelaksanaan pendidikan interprofesional. ${ }^{11}$ Tahapan tersebut ada yang dapat dilakukan di dalam kelas, di luar kelas melalui kerja praktik, masing-masing dilakukan pada pendidikan profesi dan ada yang harus melalui proses pendidikan bersama. Kesebelas tahapan tersebut adalah sebagai berikut: ${ }^{11}$

a. Isolasi (isolation). Proses ini dapat dilaksanakan di kelas, di masing-masing profesi tanpa ada kontak atau hubungan antarprofesi. Setiap profesi diajarkan tentang peran profesi mereka sendirisendiri. Pengetahuan tentang peran profesi lain dipersilahkan belajar sendiri melalui referensi yang diberikan.

b. Penyadaran (awareness). Proses pembelajaran di kelas di masing-masing profesi. Setiap profesi mulai menanamkan kesadaran tentang keberadaan profesi lain.

c. Konsultasi (consultation). Proses pembelajaran di kelas di masing-masing profesi. Setiap profesi mulai memberitahukan peran profesi lain di dalam pelayanan. Materi yang diberikan adalah hasil konsultasi para pengajar di setiap profesi.

d. Pengadaan (nesting). Proses pembelajaran di kelas atau di tempat praktik masing-masing profesi. Mahasiswa diberitahu tentang peran profesi lain terkait tugas dan fungsinya di dalam pelayanan sebagai sebuah tim.

e. Koordinasi sementara (temporal coordination). Proses pembelajaran di kelas namun dilakukan secara bersama-sama antar profesi, misalnya kuliah bersama terkait peran antarprofesi dalam pelayanan. Meskipun demikian, belum ada interaksi secara langsung atau kerjasama secara langsung dalam proses pembelajarannya, hanya bersama dalam satu jadwal tertentu.

f. Berbagi pengajaran (sharing teaching). Proses pembelajaran di kelas atau di ruangan dimana ada proses berbagi atau saling tukar sarana pembelajaran. misalnya saling berbagi atau saling tukar alat yang digunakan untuk keterampilan tertentu atau saling tukar pasien simulasi yang digunakan di masing-masing profesi. Hal ini ditujukan untuk memahami peran masing-masing profesi dan memahami juga yang dilakukan profesi lainnya. Sudah ada kerjasama antar profesi tetapi masih terfokus pada profesi masing-masing.

g. Hubungan (correlation). Proses pembelajaran di kelas atau ruangan dimana telah dijadwalkan di masing-masing profesi pembahasan bersama dengan profesi lain. Misalnya setiap kamis di kedokteran mengundang profesi atau program studi (program studi) lain (program studi keperawatan dan program studi gizi) untuk membahas peran antar profesi dalam suatu kasus, demikian juga program studi yang lain suatu waktu mengundang mahasiswa kedokteran. Sudah ada kerjasama antar profesi tetapi masih dilakukan di profesi masing-masing.

h. Menghormati (complimentary). Proses pembelajaran di kelas atau ruangan dimana mahasiswa di masingmasing profesi memiliki jadwal setengah di profesi masing-masing namun setengahnya bersama dengan profesi lain. Misalnya dalam satu blok ada sesi diskusi tutorial bersama antar profesi untuk membahas satu skenario secara bersama-sama dengan menggunakan cara pandang masing-masing profesi. Jadwal diskusi merupakan jadwal bersama antar profesi (antar program studi) yang ada. Sudah bekerjama tetapi masih sebagian-sebagian (sebagian bersama dan sebagian sendiri-sendiri).

i. Pendidikan multiprofesional (multiprofessional education). Proses pembelajaran di kelas atau ruangan dimana mahasiswa dari berbagai profesi (program studi) belajar bersama namun masih menggunakan perspektif masing-masing profesi. Misalnya ada satu blok khusus, dimana semua mahasiswa dari berbagai profesi (program studi) 
melakukan diskusi tutorial namun masih menggunakan cara pandang masing-masing profesi. Sudah kerjasama dan sudah terjadwal bersama, namun masih menggunakan cara pandang masing-masing profesi.

j. Pendidikan interprofesional (interprofessional education). Proses pembelajaran di kelas atau ruangan dimana mahasiswa dari berbagai profesi (program studi) belajar bersama dan mencoba saling menggunakan cara pandang profesi lain. Misalnya dalam satu blok khusus, dimana semua mahasiswa dari berbagai profesi (program studi) melakukan diskusi tutorial bersama, kemudian mahasiswa kedokteran mencoba menggunakan cara pandang keperawatan dan gizi, demikian juga dengan mahasiswa dari profesi (program studi) lainnya. Kerjasama antar profesi mulai dipraktikkan. Persamaan dan perbedaan antar profesi didiskusikan bersama sehingga terjadi diskusi interaktif antar profesi.

k. Pendidikan transprofesional (transprofessional education). Proses pembelajaran di tempat praktik pelayanan kesehatan, misalnya rumah sakit atau pusat pelayanan kesehatan masyarakat (Puskesmas). Mahasiswa dari berbagai profesi (program studi) bekerja bersama-sama (rotasi bersama) dalam menangani kasus atau pasien di tempat pelayanan kesehatan sebagai sebuah tim pelayanan kesehatan.

Institusi pendidikan kedokteran khususnya yang juga memiliki program studi kesehatan lain seperti ilmu keperawatan, harus mulai memikirkan cara pelaksanaan strategi pendidikan ini. Interprofessional education, sesuai dengan tahapan di atas, sebaiknya dilakukan sejak dini di tingkat sarjana sampai di tingkat profesi (rotasi klinik). Tentu saja, pembahasan tentang interprofessional education ini harus dibicarakan dengan program studi yang lain difasilitasi oleh pihak Fakultas. Selain menuntut adanya alokasi waktu di setiap kurikulum masing-masing program studi, interprofessional education juga memerlukan sistem pengelolaan dan ketersediaan sarana dan prasarana yang tidak mudah.

\section{Community Oriented Medical Education (COME)}

Banyak institusi pendidikan kedokteran telah melaksanakan COME. Fakultas Kedokteran UGM telah melaksanakan COME sejak tahun 1973 yang dikenal dengan Program Pendidikan Kedokteran Komunitas., ${ }^{50}$ Awalnya program ini diberi nama Comprehensive Community Health Care-Education Programme (CCHC-EP) yang didukung oleh Rockefeller Foundation. Pada tahun 1982, program didukung oleh Health Development in Rural Area (HEDERA) dengan NUFFIC Belanda sebagai penyandang dana. Pada saat tersebut, kedokteran komunitas dilaksanakan ditingkat sarjana dan profesi. Namun sejak tahun 1992, hanya dilaksanakan di tingkat profesi yang sekarang disebut dengan Kuliah Kerja Kesehatan Masyarakat (K3M). Mempertimbangkan standar kompetensi dokter yang harus dicapai dan kelebihan yang dimiliki COME, maka dalam rancangan inovasi pendidikan, COME menjadi salah satu inovasi yang dapat dilakukan.

COME dapat dilaksanakan di tingkat sarjana dan profesi (rotasi klinik). ${ }^{6}$ Di tingkat sarjana, COME dilaksanakan untuk pembelajaran epidemiologi, promosi kesehatan, prinsip kesehatan masyarakat, pengembangan komunitas, dampak sosial terhadap kesehatan masyarakat dan memahami interaksi pasien dengan sistem pelayanan kesehatan. ${ }^{6,8,10}$ Di tingkat sarjana, COME juga dapat digunakan untuk belajar keterampilan klinik dasar, latihan keterampilan komunikasi dan keterampilan untuk mengembangkan profesi (seperti kepemimpinan, manajemen, dan kerjasama tim). Di tingkat rotasi klinik, COME berguna untuk belajar praktik sebagai dokter umum, mengenal praktik spesialisasi tertentu di komunitas, dan belajar tentang peran berbagai disiplin atau cabang ilmu kedokteran dalam mengelola pelayanan kesehatan kepada masyarakat secara langsung atau nyata di tengah masyarakat.

Agar pelaksanaan COME dapat sukses dilaksanakan, ada empat hubungan kunci yang harus diperhatikan yaitu hubungan dokter dengan pasien, hubungan universitas dengan pusat pelayanan kesehatan, hubungan pemerintah dengan komunitas, dan hubungan pribadi (individu) dengan profesi (tuntutan profesionalisme). ${ }^{6}$ Schmidt dan Magzoub mengklasifikasikan COME dalam tiga kelompok yaitu; (1) service oriented programs, (2) research oriented programs, dan (3) training focused programs. ${ }^{10}$

Ada beberapa aspek yang harus diperhatikan dalam pengembangan COME. Aspek-aspek tersebut antara lain: ${ }^{10,12}$

a. Tujuan dan gambaran singkat kurikulum, yang meliputi; hubungan dengan pasien, manajemen 
klinis di dalam praktik kesehatan masyarakat, manajemen kesehatan dan penyakit di masyarakat, dan prinsip serta praktik memperbaiki kesehatan masyarakat.

b. Menetapkan cara pengajaran yang akan digunakan. Ada beberapa model pengajaran yang dapat dilakukan yaitu model partnership, interprofessional atau multi professional education, profession based coursework (promoting critical thinking skills), project centered learning, community oriented research, dan penggunaan teknologi informasi dan komunikasi. COME dapat dilakukan sebagai bagian setiap Blok atau dapat disusun dalam blok khusus yang ada di setiap tahun. Di rotasi klinik, harus ada stase atau rotasi khusus di komunitas.

c. Pengalaman belajar setiap tahun. Setiap tahun (tingkat) memiliki topik atau tujuan utama, misalnya; tahun pertama tentang pengenalan kesehatan masyarakat, tahun kedua tentang diagnosis masalah kesehatan masyarakat, tahun ketiga tentang pengembangan proposal program atau penelitian, tahun keempat tentang pelaksanaan program atau penelitian, dan tahun kelima (rotasi klinik) tentang praktik pelayanan kesehat an masyarakat di tempat pelayanan kesehatan masyarakat yang tersedia. Di dalam setiap topik, harus juga dijelaskan tentang domain pengetahuan (knowledge), keterampilan (skills) dan sikap perilaku (attitude) yang akan dicapai.

d. Rincian tujuan belajar setiap tahun.

e. Pembentukan tim kurikulum atau pengelola program COME dan sistem pengelolaannya.

f. Koordinasi kurikulum dengan semua bagian klinik dan pre-klinik (ilmu-ilmu dasar).

g. Pemilihan komunitas dan pusat pelayanan kesehatan masyarakat yang akan digunakan. Proses pemilihan dimulai dari proses pemilihan, penilaian kelayakan, penetapan sampai proses orientasi. Program studi harus mempersiapkan komunitas dan pusat pelayanan yang dipilih sebagai tempat belajar.

h. Pendokumentasian kurikulum

i. Pembuatan nota kerjasama antara institusi pendidikan dengan pihak yang berwenang di komunitas dan pusat pelayanan kesehatan masyarakat yang akan digunakan. Dalam nota kerjasama harus dibahas tentang masalah akomodasi, transportasi, materi pembelajaran (sumber belajar), fasilitas makan minum, dan aspek rekreasi yang memungkinkan.

j. Penetapan pembimbing ditingkat institusi dan lapangan, lengkap dengan peran dan tugasnya. Para pembimbing harus mendapatkan pelatihan menjadi pembimbing.

k. Ringkasan kegiatan belajar mahasiswa yang akan dilaksanakan.

Sistem penilaian mahasiswa adalah faktor yang juga harus diperhatikan dalam pelaksanaan COME. Ada dua jenis penilaian yang digunakan yaitu formatif dan sumatif. ${ }^{10}$ Penilaian formatif di dalam COME ditujukan untuk menilai kemampuan mahasiswa dalam mencapai tujuan belajar di setiap tahapan. Metode penilaian yang dapat digunakan antara lain; pilihan ganda atau multiple choices question (MCQ), ujian lisan, modified essay questions, patient management problems, simulasi computer (computer simulations), objective structured clinical examination (OSCE), standardized patients, direct observation, logbook, self directed learning tests, dan tes kerjasama kelompok (group collaboration test). Penilaian formatif diharapkan mampu memberikan umpan balik (feedback) kepada mahasiswa untuk meningkatkan proses pembelajaran dan kepercayaan diri mereka. Penilaian sumatif ditujukan untuk menilai kemampuan mahasiswa secara terintegrasi keseluruhan aspek COME. Metode penilaian yang dapat digunakan antara lain; log book, medical record review, simulated patient encounters, laporan pembimbing (supervisor's/perceptor's report), critical incident approach, laporan kegiatan (project report) dan presentasi.

Tak kalah pentingnya dalam COME adalah penggunaan teknologi informasi dan komunikasi. ${ }^{6,8}$ Pengembangan sistem informasi berupa jaringan informasi antara institusi pendidikan dan komunitas (termasuk tempat pelayanan kesehatan masyarakat) yang digunakan sangat membantu proses pendidikan. Sistem informasi yang dibuat adalah sama seperti yang telah dijelaskan sebelumnya. Dengan demikian, mahasiswa ketika di komunitas tetap dapat mengakses sekaligus memberikan informasi terkait kegiatan yang dilaksanakan di komunitas.

\section{Elective}

Ada beberapa faktor yang harus diperhatikan dalam penyusunan dan pelaksanaan program elektif. ${ }^{6}$ Faktorfaktor yang harus diperhatikan dalam penyusunan program adalah; (1) ketersediaan sumber daya, baik 
sarana fisik maupun sumber daya manusia, (2) antusiasme staf atau dosen untuk menyelenggarakan program, (3) proses belajar sebelumnya (prior learning), (4) luasnya cakupan pengalaman belajar yang akan diperoleh mahasiswa, dan (5) pengorganisasian kurikulum secara keseluruhan. Faktor-faktor yang harus diperhatikan dalam pelaksanaan program elektif adalah; (1) kejelasan hasil belajar (learning outcome) yang akan dicapai mahasiswa dalam program terutama terkait area kompetensi dokter, misalnya kejelasan hasil belajar terkait keterampilan komunikasi, (2) metode pengajaran, pembelajaran dan sistem penilaian yang akan digunakan, dan (3) struktur program terkait kurikulum keseluruhan. ${ }^{6}$

Inovasi yang dapat dilakukan dalam program elektif didasarkan pada proses penyusunan dan pelaksanaan program elektif. Terkait proses penyusunan, institusi pendidikan dapat mengevaluasi program yang sekarang berlangsung dihubungkan dengan kebutuhan atau keinginan mahasiswa yang sebenarnya akan program elektif yang seharusnya ada. Proses pemilihan program elektif dapat dilakukan dalam 3 cara, yaitu (1) mahasiswa memilih program yang disarankan dosen, (2) mahasiswa memilih program yang disediakan oleh institusi pendidikan, dan (3) mahasiswa mengusulkan program elektif yang dibutuhkan atau diinginkannya. ${ }^{6}$ Terkait proses pelaksanaan program elektif, inovasi yang dapat dilakukan adalah optimalisasi modul, penetapan standar modul yang lebih ketat, penggunaan sistem teknologi informasi, penyedian panduan belajar (study guide), dan sistem evaluasi pelaksanaan modul yang terpadu. Selain itu, inovasi yang perlu dilakukan adalah dengan membuka kemungkinan elektif dengan institusi pendidikan kedokteran di Universitas lain baik di tingkat nasional maupun internasional. Hal ini berguna untuk memperluas wawasan dan pengembangan profesi mahasiswa. Untuk mewujudkannya, suatu institusi pendidikan harus terlebih dahulu membuat hubungan kerjasama dan menetapkan standar bersama tentang program elektif yang dapat dilaksanakan, sehingga keterkaitan atau hubungan antara kurikulum inti dengan kurikulum elektif tetap dapat dijaga.

\section{Systematic}

Pendekatan sistematis harus dilaksanakan terkait dengan beberapa faktor di bawah ini: ${ }^{1,6}$

- semakin banyaknya variasi spesialisasi dalam praktik kedokteran.
- kebutuhan untuk menjamin bahwa mahasiswa mendapatkan seluruh pengalaman belajar yang dibutuhkan.

- tuntutan KBK dimana proses pembelajaran harus terkait secara jelas dengan kompetensi yang ingin dicapai.

- adanya kompetensi dokter yang harus dicapai sebelum terjun di pelayanan kesehatan yang sesungguhnya.

Pendekatan sistematis dapat tercapai melalui kejelasan, kesinambungan, keterpaduan dan keteraturan sistem pendidikan yang dilaksanakan. Menjadi tugas institusi pendidikan untuk meyakinkan bahwa mahasiswa telah mengikuti proses pendidikan dan telah mencapai kompetensi yang telah ditetapkan sebelumnya.

Inovasi yang dilaksanakan antara lain dengan penyediaan panduan akademik, panduan belajar (study guide) yang jelas, pelaksanaan sistem log book, pelaksanaan portofolio, sistem umpan balik (feedback), dan penggunaan sistem teknologi informasi serta komunikasi. ${ }^{6,8}$ Panduan akademik akan memberikan arahan dan gambaran tentang seluruh proses pendidikan yang akan dilalui mahasiswa. Panduan belajar diperlukan untuk memudahkan mahasiswa dalam proses belajar dan pencapaian kompetensi. Log book membiasakan mahasiswa mencatat dan merekam pengalaman belajarnya sendiri sebagai bukti proses yang telah dilaluinya. Portofolio yang merupakan kumpulan hasil pekerjaan mahasiswa (misalnya laporan, daftar tilik keterampilan yang dilaksanakan, video rekaman konsultasi, laporan penelitian, dan penghargaan kegiatan mahasiswa) sebagai bukti pencapaian pengetahuan, keterampilan, sikap, perilaku, pemahaman dan perkembangan profesionalisme akan membiasakan mahasiswa melakukan refleksi terhadap berbagai pengalaman dan pencapaiannya tersebut. Sistem umpan balik (feedback) yang seharusnya menjadi bagian seluruh proses pendidikan namun pada kenyataannya masih lemah, akan membantu mahasiswa untuk memperbaiki dan meningkatkan proses pembelajaran dan pencapaian kompetensi secara terus menerus jika dilakukan dengan benar. Penggunaan sistem informasi yang mampu memfasilitasi seluruh proses di atas (penyediaan panduan akademik, belajar, $\log$ book, portofolio dan feed back), akan sangat berguna dalam memperlihatkan kejelasan sistematika pola pendidikan kepada seluruh sivitas 
akademika dan juga berbagai pihak yang berkepentingan. Penggunaan teknologi komunikasi seperti multimedia juga akan sangat membantu proses belajar mengajar, penilaian sampai kepada proses evaluasi program. Keseluruhan rancangan inovasi yang ditawarkan akan sulit terwujud tanpa dukungan sistem pengelolaan (manajemen), administrasi dan evaluasi program yang baik

\section{KESIMPULAN}

Inovasi pendidikan kedokteran pada dasarnya adalah reaksi terhadap berbagai tuntutuan dan perubahan yang terjadi di lingkungan institusi pendidikan kedokteran. Inovasi strategi pendidikan adalah bagian dari upaya tersebut. Setiap melakukan suatu inovasi, institusi pendidikan kedokteran harus mempertimbangkan tingkat kelayakan, sumber daya yang dibutuhkan, waktu dan durasi pelaksanaan, skala dan derajat, kegagalan yang dapat terjadi, hambatan yang dihadapi dan pola inovasi yang akan dilakukan. Dengan mempertimbangkan kondisi terkini suatu institusi pendidikan kedokteran yang diketahui melalui hasil evaluasi diri dan rencana strategis, serta trend yang berkembang dalam dunia pendidikan kedokteran saat ini, maka sejumlah usulan inovasi dapat dilakukan. Pendekatan SPICES dapat diambil sebagai panduan dalam merancang inovasi. Selain merupakan kecenderungan yang sedang bergulir di dunia pendidikan saat ini, SPICES merupakan strategi pendidikan yang ditetapkan KKI sebagai strategi pendidikan utama di institusi pendidikan kedokteran seluruh Indonesia sebagaimana tertulis dalam Standar Pendidikan Profesi Dokter.

\section{DAFTAR PUSTAKA}

1. Majumder A, D'Souza U, Rahman S. Trends in medical education: challenges and directions for need- based reforms of medical training in South-East Asia. Indian J of Med Sci. 2004;58:369-80.

2. World Federation of Medical Education. WFME: global standards for quality improvement. Copenhagen: WFME, 2003.

3. Konsil Kedokteran Indonesia. Standar pendidikan profesi dokter konsil kedokteran Indonesia. Jakarta: KKI, 2006.

4. Konsil Kedokteran Indonesia. Standar kompetensi dokter Indonesia konsil kedokteran Indonesia. Jakarta: KKI, 2006.

5. Fakultas Kedokteran UGM. 60 Tahun Fakultas Kedokteran UGM. Yogyakarta: FK UGM, 2006.

6. Dent JA, Harden RM, editors. A practical guide for medical teachers. $2^{\text {nd }}$ ed. London: Elsevier Churchill Livingstone, 2005.

7. Gale R, Grant J. AMEE medical education guide No.10: managing change in a medical context: guidelines for action. Med Teach. 1997;19(4): 239. 5.

8. Work JA, et al. Innovations in medical education: the medical college of Georgia school of medicine experience. Southern Med J. 2003;96(9): 840-4.

9. Tan GJS, Baumber JS. Development and implementation of a cardiovascular system course at the international medical college: a new innovation in medical education. Med Teach. 1999; 21(2):1939.

10. Schmith H, Magzoub M, Feletti G, Nooman Z, Vluggen P. Hand book of community - based education: theory and practice. Maastricht: Network Publications, 2000.

11. Harden RM. AMEE guide No. 12: Multi-professional education: part 1-effective multi-professional education: a three-dimensional perspective. Med Teach. 1998; 20(5):402-8.

12. Howe A. Twelve tips for community-based medical education. Med Teach. 2002;24(1): 9-12. 